v. 14, n. 1

Vitória-ES, Jan.-Feb. 2017

p. $110-132$ ISSN 1808-2386

\title{
Corporate Image: Influencing Factors from the Viewpoint of Students of Distance Learning Courses
}

\author{
Fábio Reis da Costa ${ }^{\dagger}$ \\ Foundation of Support to the Technical School of the State of Rio de Janeiro - FAETEC \\ State University of North of Fluminense Darcy Ribeiro - UENF
}

Anderson Soncini Pelissari ${ }^{\Omega}$

Federal University of Espírito Santo - UFES

\begin{abstract}
New information technologies enable different interactions in the educational environment, affecting how students perceive and construct images about educational institutions that have adopted distance-learning programs. This article identifies which factors are associated with the perception of corporate image, from the viewpoint of distance-learning students at public higher-education institutions. The proposed study is quantitative in nature. The research analysis units are Higher Education Institutions in the State of Rio de Janeiro (Brazil) that offer e-Learning undergraduate courses in the CEDERJ consortium. The units of observation are students enrolled at the São Fidélis hub. Data were collected using a questionnaire and analyzed using the SPSS program. The study demonstrated both the multidimensionality of the image and that the institution's Global Image is associated most strongly with its "Quality". In turn, "Virtual Environment" was the factor most strongly associated with Affective Image.
\end{abstract}

Keywords: CEDERJ. Corporate image. E-Learning course. Higher education.

Received on 10/23/2015; Reviewed on 11/30/2015;Accepted on 04/18/2016; Divulgued on 01/02/2017.

*Author for correspondence:

$\doteqdot$ Master in Administration by the Federal University of Espírito Santo - UFES.

Link: Professor of the Foundation of Support to the Technical School of the State of Rio de Janeiro - FAETEC;

Administrator of the Universidade Estadual do Norte Fluminense Darcy Ribeiro - UENF.

Address: Alberto Lamego Avenue, 2000, Califórnia Park, Campos dos Goytacazes - RJ - Brazil. Cep. 28013-602

E-mail: reis.frc@gmail.com
$\Omega$ Doctor in Engeenering of Production by the Metodista University of Piracicaba - SP.

Link: Professor of the Postgraduate Program in Administration Master and Doctorate - PPGADM / UFES, Professor of the Administration Department and Researcher of the Research Line Strategy, innovation and organizational performance - Center for Studies in Technologies and Organizational Processes - TecPrO Address: Fernando Ferrari Avenue, 514, Goiabeiras - Vitória, ES Brazil. Cep. 29075-910.

E-mail: asoncinipelissari@gmail.com 


\section{INTRODUCTION}

Brazilian higher education market, according to the United Nations Educational, Scientific And Cultural Organization - UNESCO (2012), taking into account the number of students, is the fifth largest in the world, and the largest in Latin America. However, its market penetration level is at 27\%, much lower than other developing countries, signaling a growth potential for the sector (UNESCO, 2012).

According to the National Institute of Educational Studies and Research Anísio Teixeira - INEP (2013), the volume of enrollments (between on-campus and distance) in public higher education increased by $74 \%$ between 2002 and 2012, surpassing the 1.9 million mark of students enrolled between 2012 and 2013 (INEP, 2014). Distance Learning was responsible for such growth in the public schooling system, since its enrollments between 2011 and 2012 increased by $12.2 \%$ whilst on-campus learning, offered growth of only $3.1 \%$ (INEP, 2013). By comparing entries in the public network, Distance Learning presented an increase of $42.53 \%$, whilst the private network's index was $24.28 \%$.

Kundi, Nawaz and Khan (2010) advocate that all projects for Distance Learning, in addition to its form, pedagogy, environment and tools used in the process, is a function of perceptions created by their audiences, being a decisive factor for their success. Thus, such growth challenges educational institutions to create and organize an appropriate administrative and technological infrastructure, which allows interaction between the faculty, students and staff in addition to requiring that both, their educational proposals, as the quality of teaching and learning be highlighted (BOAS et al., 2011).

That said, Paden and Stell (2006) claim that Higher Education Institutions that adopt Distance Learning programs must be alert to the impact this action has on the image of their programs and perceptions of the institution as a whole, thus it is added by Slavov and Slavov (2010), Distance Learning brings together students from the most varied backgrounds, interacting in the virtual environment.

Within this scenario, it is essential to question: what factors are associated with Corporate Image, from the viewpoint of Distance Learning students of Public Higher Education Institutions? The objective of this research is to answer this question, based on the methodology used in the study by Palacio, Meneses and Pérez (2002), and among all the variables presented in this study, we will select those that adapt to the Brazilian reality, the objectives of the present study, and to the particularities of Distance Learning. 
Amongst the research on image of higher education institutions, we can highlighted the studies by Palacio, Meneses and Pérez (2002), Duarte, Alves and Raposo (2010), Maric, Pervlin and Ferjan (2010), Polat (2011), Cervera et al. (2012), Azoury, Daou and Khoury (2014) and by Costa Vieira and Couto (2015), all aimed at raising the factors that impact the formation of the image of such institutions. Regarding Distance Learning, on the other hand,we find studies by Claro (2007), Hasan and Laaser (2010), Spíndola and Mousinho (2012) and Hackmayer and Bohadana (2014).

Thus, the interest in this research is included in the observation by Abbad, Zerbini and Souza (2010) who point out that it is the volume of conducted research regarding Distance Learning incompatible with the significant increase in the importance of this type of education in the national panorama; combined with the analysis by Mondini et al. (2014) who emphasize research aimed at distance learning being incipient, in which strategies that influence the choice of a higher education institution can be measured; added to the fact that the interactivity involving such form of education increases the importance of knowing what is more or less valued by students in the development of this model (LANDRY; GRIFFETH; HARTAMAN, 2006) and the corporate image being little explored in the field of nonprofitable organizations (AZOURY; DAOU; KHOURY, 2014).

Thus, we seek through this research, to contribute to a better understanding of the perception of the image of higher education institutions, from Distance Learning students' viewpoint, contribute to a better understanding of the factors that are associated with the image of higher education institutions, more specifically of public institutions, in addition to demonstrating how marketing can be used in favor of such institutions and provide a basis for future research on the subject.

\section{THEORETICAL FRAMEWORK}

\subsection{CORPORATIVE IMAGE}

Liou and Chuang (2010) indicate there is no agreement on the concept of corporate image accepted among scholars in the field. Therefore, Azoury, Daou and Khoury (2014) address that there is a disagreement in the effort to define it.

Da Costa Vieira and Couto (2015) define image as the result of a complex evaluation of recent observations on the institution, contradicting the concept by Azoury, Daou and Khoury (2014) who define it as a product of perceptions by their audiences over time. 
Clemente and Jeunon (2012) went further, stating in their concept the idea that the image summarizes sensations and feelings present in the individual's mind, depending on what they perceive and observe in the world around them, corroborating Nguyen and Leblanc (2001) which they addressed that individuals select and retain in mind, consciously or not, realities formed by the company to which they are exposed, compatible with their beliefs and behavior and recovering the memory to develop the company's image.

Thus, Wilkins and Huisman (2013) added that it is up to managers to observe how the signs of corporate identity are transmitted and decoded by stakeholders as an attractive organizational image. Such thinking is in line with Abratt and Kleyn (2012) in defining that a positive image is obtained, before the audience, with a purposefully and strategically planned self-presentation of their identity

That said, Polat (2011) indicates that the image is formed by a process that requires a long period of time. On the other hand, Balmer and Grayser (2006) disagree with the notion of image formation as a process, in considering that the corporate image is an answer to the question: "How is the company being perceived now?".

We can see the complex and dynamic characteristic of Corporate Image (SUNG; YANG, 2008). Thus, despite the various definitions, all have the concept of representation, impression or mental interpretations in common (TUBILLEJAS; CUADRADO; FRASQUET, 2011), combining affective, cognitive and sensory elements (SCHULER; 2004) and is therefore based on the information and data gathered in these interactions with the organization (POLAT, 2011).

Azoury, Daou and Khoury (2014) indicate that corporate image has essentially multiple dimensions, corroborating Dowling (1986), who also emphasizes that it is rare only one factor demonstrating completely the image of the institution. In this sense, Azoury, Daou and Khoury (2014), in their research with students from universities in eight Middle Eastern countries, indicate that the affective aspect is associated with the cognitive aspect of the image, and that the greatest influence from the global image is exercised by the affective aspect of the image.

Palacio, Meneses and Pérez (2002) also observed that the cognitive and affective aspects, which are interrelated, form the global image, and this determines the satisfaction of users of such institutions. The cognitive element refers to tangible attributes that can be measured by the organization, and the affective concerns those associated with psychological 
aspects manifested through behaviors and feelings about the organization (PALACIO; MENESES; PÉREZ, 2002).

Duarte, Alves and Raposo (2010) addresses that several studies indicate a consensus that the organizational image is formed by several factors; it is multidimensional (PALACIO; MENESES; PÉREZ, 2002; DUARTE; ALVES; RAPOSO, 2010; MARIC; PERVLIN; FERJAN, 2010; CERVERA et al, 2012; AZOURY; DAOU; KHOURY, 2014). For this study, we will adopt the concept by Berens and Van Riel (2004) who establish that the corporate image is a compound formed by the use of goods and services, influence of others, reputation of the institution, communicative actions, by the set of experiences of consumers and personal perceptions, translated into impressions, beliefs and feelings about the organization.

\subsection{THE CEDERJ CONSORTIUM}

Pithon et al. (2010) inform that the Government in the State of Rio de Janeiro created the CEDERJ consortium - Higher Distance Learning Centre of the State of Rio de Janeiro, in the year 2000. CEDERJ is a consortium consisting of the UFRJ - Federal University of Rio de Janeiro, UFF - Federal Fluminense University, CEFET - Federal Center of Technological Education Celso Suckow da Fonseca, UENF -Norte-Fluminense Darcy Ribeiro State University, UERJ - Rio de Janeiro State University, UNIRIO -Federal University of Rio de Janeiro State and UFRRJ - Federal Rural University of Rio de Janeiro (CEDERJ, 2014).

Having integrated the Open University System of Brazil since 2005 (FIRMINO; VIEIRA, 2013), nowadays CEDERJ serves more than 30 thousand students (CEDERJ, 2015) in 33 hubs distributed across the state of Rio de Janeiro (HASAN; LAASER, 2010). Thus, the following courses are offered: Administration, Public Administration, Chemistry, Languages, Mathematics, History, Physics, Geography, Biological Sciences, Pedagogy, Tourism, Production Engineering, Technology in Tourism Management, Technology in Public Security and Technology in Computer Systems (CEDERJ, 2015).

Spíndola and Mousinho (2012) observe that the integration of classroom and online activities confer the CEDERJ a hybrid model, based on print and digital educational resources developed specifically for Distance Learning; on-campus and distance tutorial systems; supervised internship and assessment performed in the teaching hubs, in person. Within this framework, it is the responsibility of the CECIERJ Foundation, the production of learning materials, as well as managing the teaching support platform (HASAN; LAASER, 2010). 
The physical structure that houses the hubs, is mostly provided by the city municipalities (HASAN; LAASER, 2010), who is also responsible for the assignment of administrative staff (SOUZA NETO et al., 2010). As for the provision of materials and other resources necessary for its operation, including financial ones for the remuneration of all human resources, is the responsibility of the CECIERJ Foundation - Science Center and Higher Distance Learning of the State of Rio de Janeiro, an agency linked to the Science and Technology State Department (SOUZA NETO et al., 2010).

Angulo Meza, Soares de Mello and Gomes Júnior (2012) add that educational projects are based on the technological development and they include, in addition to the use of information and communication technologies, practical classes in laboratories. Souza Neto et al (2010) also note that universities are responsible for the educational projects of each course, as also added by Hasan and Laaser (2010), the academic activities of each course. The responsibility and preparation of the evaluations belongs to the coordination of each course, linked to institutions offering the course in the hub (BIELSCHOWSKY, 2005).

To support students, tutors guide their learning, through the use of expertise and mastery of techniques inherent to distance learning (GARCIA; SEMENSATO, 2015), clarify students' doubts and, whether in person or by distance via the Internet, or through free phone calls (SOUZA NETO et al., 2010). Claro (2007) elucidates that undergraduate or graduate training is required from the mentoring team, who cannot be, as Hackmayer and Bohadana (2014) add, an integral part of the teaching staff of the consortium institutions

Comin, Oliveira and Possa (2013) examined the relationship between tutors and the institutional image, by seeking answers to questions related to the capabilities of tutors in the Distance Learning process in public higher education institutions. The authors found that the tutors, in the process of Distance Learning in public higher education institutions, create value with the students, so that their performance influences the institutional image that is communicated to society.

On the CEDERJ platform, students have many resources available such as forums, chats, the possibility of messaging other students, communication with teachers, receiving notices, schedule of activities, tests, lessons, lesson plans, in addition to the possibility to download supporting materials for the disciplines (SPÍNDOLA; MOUSINHO, 2012). Souza Neto et al (2010) emphasize interactivity and the possibility that the platform offers to integrate the various parties involved in the teaching-learning process, a process that can be 
favored by increased motivation and interest of Distance Learning students, due to the positive assessment of the elements present in the process (KUNDI; NAWAZ; KHAN, 2010).

The CECIERJ (2014) explains that students' diplomas have the name of the university offering the course in the hub chosen by them, because students are considered as students of each university. Moran (2009) states that since all the institutions of the consortium are public, the courses are offered for free.

The Ministry of Education and Culture - MEC (2001), through its evaluation committee constituted for the approval of the CEDERJ project, highlights the innovative character of the project, especially with regard to the pooling of efforts to optimize the use of public resources. The MEC (2001) proceeds and highlights that there is no precedent, in proposals for distance learning, a project that is so innovative as the constitution of the CEDERJ.

\section{METHODOLOGICAL ASPECTS OF THE RESEARCH}

Concerning the means of research, the study is classified as a field research, being empirical, with local application of questionnaires where the phenomenon takes place, and it is descriptive on its purposes, demonstrating population characteristics, establishing correlations between variables (VERGARA, 2010). The research is cross-sectional because each respondent was interviewed in a single space in time (RINDFLEISCH, 2008); quantitative, for having dealt with the use of statistics the information collected for resolution of the problem (GREENER, 2008), allowing to confirm the relations of phenomena and generalize its occurrence or meaning (LAKATOS; MARCONI, 2010).

We used a survey, according to Hair Junior et al. (2005), which is the study employing a structured questionnaire to gather information from a representative sample of the population. The study used as its analysis unit Public Higher Education Institutions, from the state of Rio de Janeiro, that offer undergraduate on-line courses in the CEDERJ consortium, in the hub of São Fidélis.

The choice for the state of Rio de Janeiro is related, as is highlighted by Claro (2007), to the pioneering of the CEDERJ consortium in making use of printed material, distance and oncampus tutorials, combined with a virtual learning environment, coupled with the emphasis that was given by MEC (2010) and the innovative nature of the CEDERJ project. The choice for the São Fidélis hub is due to convenience, because of the researcher's proximity with the city where the hub is located, and ease of access to information and research sources. 
The study population included all students enrolled in the second half of 2014, regardless of the area where they started their distance course in the first half of 2014, to understand entering students; and students enrolled in the second half of 2014, of the distance learning course, regardless of the area, and with more than three years of course, to comprise students near completion.

The total of enrolled entering students was 95, and the ones near completion was 182, distributed among the courses of Administration, Computing and Bachelors in Biological Sciences, Mathematics, Pedagogy and Chemistry. However, from that number, students attending totaled 48 entrants and 60 students near completion. Richardson (1999) indicates that one can define the minimum sample size in the case of a finite universe through the equation:

$$
\mathrm{n}=\frac{\mathrm{S}^{2} \cdot \mathrm{p} \cdot \mathrm{q} \cdot \mathrm{N}}{\mathrm{e}^{2}(\mathrm{~N}-1)+\mathrm{S}^{2} \mathrm{p} \cdot \mathrm{q}}
$$

Where:

$\mathrm{n}$ : the sample size;

s: confidence level chosen in number of standard deviations;

p: percentage of sample elements favorable to the phenomenon;

q: percentage of sample elements unfavorable to the phenomenon, i.e., 100-p.

$\mathrm{N}$ : size of the population;

E: maximum acceptable error estimation, in percentage.

Thus, we have reached the minimum number of 85 respondents, according to the calculation of the following equation:

$$
\mathrm{n}=\frac{2^{2} .50 .50 .108}{5^{2}(108-1)+2^{2} .50 .50}
$$

Chin, Marcolin and Newsted (2003) observe that the sample must be calculated considering, at least, ten respondents multiplied by the number of indicators of the construct with the largest number of indicators. Hair Junior et al. (2005) further establish that the 
minimum number of elements for performing a factor analysis is 50 respondents, the rule being the minimum amount of five times more observations than the construct with more indicators, where ten times more observations is preferable. Considering that in this study, the "Learning" construct is the one with the largest number of indicators, in this case 8 , then 80 would be the number of observations to be surveyed. Thus, the sample has a greater number of observations than that established by the authors Chin, Marcolin and Newsted (2003) and Hair Junior et al. (2005).

Table 1 - Demonstrating the Composition of the Sample Stratified by Course

\begin{tabular}{|c|c|c|c|c|c|c|}
\hline Course & Institution & Entrants & $\%$ & Graduating & $\%$ & Total \\
\hline Administration & UFRRJ & 14 & 37.84 & 12 & 25 & 26 \\
\hline Biology & UENF & 8 & 21.62 & 10 & 20.83 & 18 \\
\hline Computing & UFF & 2 & 5.26 & 1 & 2.08 & 3 \\
\hline Mathematics & UFF & 2 & 5.26 & 2 & 4.17 & 4 \\
\hline Pedagogy & UNIRIO & 10 & 26.32 & 18 & 37.5 & 28 \\
\hline Chemistry & UENF & 1 & 2.63 & 5 & 10.42 & 6 \\
\hline \multicolumn{2}{|c|}{ TOTAL } & 37 & 100 & 48 & 100 & 85 \\
\hline
\end{tabular}

Source: Prepared by the author (2015)

In order to select students for the sample, we used the list of students, by the course, in alphabetical order, regularly enrolled, excluding those who did not fit the right profile, as previously mentioned. The sample included the first students appearing on the list until it reached the defined amount, according to Table 1.

The research used a structured questionnaire, through which the variables were measured using 37 closed questions, using a six-point Likert scale to perform the data collection, varying from 1 to 6 , divided into agree/disagree, where the closest to six represents the most agreed with the statement, and the closest to 1 represents disagreement with the statement. The choice for the six-point scale is justified as we intended to avoid the central tendency error, requiring from the respondent the agreement or disagreement on the issues of research.

The choice for the six-point scale is based on the studies by Garland (1991) who confirmed that the omission of the central point prevents individuals from giving neutral responses when their intent is to not displease the researcher with negative answers. Thus, the results may be distorted due to the existence of the center point (GARLAND, 1991).

The scale for measuring the Affective Image was taken from the study by Palacio, Meneses and Pérez (2002), and for the Global Image we adapted the scale from the study by Tubillejas, Cuadrado and Frasquet (2011). Meanwhile, the scale for assessing the Cognitive Image was based on studies by Palacio, Meneses and Pérez (2002). 
Thus, of the 21 variables addressed by Palacio, Meneses and Pérez (2002), we withdrew from the study variables related to the value of monthly payments, the number of students in class, the number of courses offered, the physical facilities and the elitism level of the institution. On the other hand, we added variables on communication and advertising, virtual environment and those related to the activities of tutors. Finally, the other variables were adapted to the daily life of Distance Learning, since the study by Palacio, Meneses and Pérez (2002) was performed in an on-campus higher education institute.

A pre-test was performed from 14 to 16 of October 2014, with the application of the questionnaire to students who joined the institutions between the second half of 2012 and the second half of 2013, so to avoid losing the research population. The date was chosen because it was a period where students should deliver, at the São Fidélis hub, their activities reports.

The pre-test was applied to 18 respondents, who answered the printed data collection instrument. The pre-test indicated that many did not know the area of the course where they studied in; the need to reduce the text on completing instructions, although there were no problems in its interpretation. There were suggestions to change the final part for 18 questions (from "...with the course objectives" to “...coherent with your course") and 20 (from "...they are current" to "...with the current world"). Thus, the variables were operationalized, as shown in Table 2, below, and the questionnaire applied on days 15, 16, 29 and 30 November 2014, date on which the students performed their classroom assessments at the São Fidélis hub.

\begin{tabular}{|c|c|c|}
\hline \multicolumn{3}{|r|}{ Variables } \\
\hline \multicolumn{3}{|r|}{ Cognitive Image } \\
\hline \multirow{7}{*}{$\begin{array}{c}\text { General } \\
\text { characteristics } \\
\text { of the } \\
\text { institution }\end{array}$} & V01 & Ease of admission \\
\hline & V02 & Innovative image \\
\hline & V03 & Effective advertisements \\
\hline & V04 & Coherent communication \\
\hline & V05 & Requirement level of admission examinations \\
\hline & V06 & Reputation \\
\hline & V07 & Time of existence \\
\hline \multirow{5}{*}{$\begin{array}{c}\text { Virtual } \\
\text { Environment }\end{array}$} & V08 & Innovative teaching \\
\hline & V09 & Easy access to learning materials \\
\hline & V10 & Ease of use of the platform \\
\hline & V11 & Quality of the platform \\
\hline & V12 & Interface facilitator of EAD activities \\
\hline \multirow{5}{*}{$\begin{array}{l}\text { Staff and } \\
\text { Tutors }\end{array}$} & V13 & Correct information \\
\hline & V14 & Willingness to solve problems \\
\hline & V15 & Deadline for reply \\
\hline & V16 & Trained tutors \\
\hline & V17 & Qualified tutors \\
\hline \multirow[t]{5}{*}{ Teaching } & V18 & Coherence of disciplines \\
\hline & V19 & Favorable curriculum for the employment market \\
\hline & V20 & Updated content \\
\hline & V21 & Coherent evaluations \\
\hline & V22 & Evaluations compatible with the EAD \\
\hline
\end{tabular}




\begin{tabular}{|c|c|l|}
\hline \multirow{4}{*}{$\begin{array}{c}\text { Services } \\
\text { Provided }\end{array}$} & V23 & Course demanding level \\
\cline { 2 - 3 } & V24 & Sufficient practical activities \\
\cline { 2 - 3 } & V25 & Preparation for the employment market \\
\cline { 2 - 3 } & V27 & Information about services \\
\cline { 2 - 3 } & V28 & Quality academic services \\
\cline { 2 - 3 } & V29 & Services provided to the community \\
\cline { 2 - 3 } & V30 & Society recognition \\
\cline { 2 - 3 } & V31 & Improvement of academic services \\
\hline \multirow{3}{*}{ Environment } & V32 & Environment favorable to communication \\
\cline { 2 - 3 } & V33 & Environment favorable to study \\
\cline { 2 - 3 } & V34 & Stimulating environment \\
\hline \multicolumn{2}{|c|}{ Global Image } \\
\hline \multirow{2}{*}{ General } & V35 & Personal perception \\
\cline { 2 - 3 } Impression & V36 & Image of the company \\
\cline { 2 - 3 } & V37 & Image compared to other institutions \\
\hline
\end{tabular}

Table 2 - Scales used in the collection instrument

Source: Prepared by the author (2015)

\section{RESULTS PRESENTATION}

\subsection{VERIFICATION OF THE AFFECTIVE IMAGE AND GLOBAL IMAGE SCALES}

Data were tabulated and analyzed through the program SPSS Statistical 20 (Statistical Package for Social Sciences). First, the emotional and overall image of scales were verified, ascertaining correlation between items of variables of the affective and global images. The correlations presented values greater than 0.40. Hair Junior et al. (2005) indicate the value of 0.30 as being significant for this type of correlation, in order to evaluate the internal consistency of a scale.

The reliability of data was observed by means of Cronbach's alpha, which, according to Hair Junior et al. (2005), checks how a latent one-dimensional dimension is explained by a group of variables. The results indicated that the Cronbach's alpha values, for both the affective image scale (0.763) as for the global scale (0.808), presented values greater than 0.75 , therefore, with an appropriate internal consistency index.

The results of the factor analysis revealed the one-dimensionality of each of the scales, and that all variables are strongly correlated with the extracted factor, since the lowest value of the load factor was 0.782 , with significant loads greater than or equal to 0.50 (HAIR et al, 2005). On the other hand, the value of the variance, that checks how much each of the three variables explains the factor extracted (LEVINE et al., 2008), reached values greater than $68 \%$ for affective image, and $72 \%$ for the global image, which are considered satisfactory for the social sciences (HAIR JUNIOR et al., 2005).

The use of factor analysis as a verification technique was adequate, considering that the KMO values for the global image were 0.705 ; and 0.674 for the affective image, with values BBR, Braz. Bus. Rev. (Engl. ed., Online), 
between 1 and 0.50 being considered acceptable, according to Aranha and Zambaldi (2008). Based on the results generated by SPSS in using our data, we can confirm the internal reliability and verify the one-dimensional nature of the affective image and global image scales, with two variables being created, termed as "Affective Image" and Global Image", condensed through factor analysis.

\subsection{COGNITIVE IMAGE SCALE VERIFICATION}

We verified the cognitive image scale basically following, the same steps and aiming at the same objectives of the verification of affective and global image scales. We deleted the variables on the improvement of services (V31), on requirement level of admission examinations (V5) and on the level of competition (V1), before conducting the factor analysis, by contributing with its withdrawal, for the increase of Cronbach's alpha, which at the end of the process presented the value of 0.906 , with 0.6 being the minimum accepted in social sciences (HAIR JUNIOR et al., 2005).

To perform the factor analysis, we used the method of principal components, through the VARIMAX orthogonal rotation. Reio and Shuck (2015) observe that the method of principal components aims to reduce the variables into fewer factors, so that they comprise a maximum variance value. On the other hand, Corrar, Paulo and Dias Filho (2009) indicate that the VARIMAX rotation favors the relationship of a variable to a single factor, reducing the possibility of a variable presenting high factor loadings related to more than one of the factors.

All other 28 variables went through a factor analysis. Rotations were performed aiming to achieve a result in which all the variables presented significant factor loadings; that such significance should not appear in more than one factor; and that its relationship with the raised factors were high, following the criteria of Hair Junior et al. (2005). In the extraction, seven factors were collected, and the variables grouped between them, as shown in Table 3 below.

\begin{tabular}{|c|l|l|}
\hline Factors & \multicolumn{1}{|c|}{ Label } & \multicolumn{1}{c|}{ Variables } \\
\hline F01 & Virtual Environment & V10. Ease of use of the platform \\
& & V09. Easy access to learning materials \\
& & V12. Interface facilitator of EAD activities \\
& & V11. Quality of the platform \\
\hline F02 & Tutors and Staff & V15. Deadline for reply \\
& & V16. Trained tutors \\
& & V14. Willingness to solve problems \\
& & V28. Quality administrative services \\
& & V30. Society recognition \\
\hline F03 & Evaluation and Content & V22. Evaluations compatible with the EAD \\
& & V21. Coherent evaluations \\
& & V18. Coherence of disciplines \\
\hline
\end{tabular}




\begin{tabular}{|c|l|l|}
\hline & & $\begin{array}{l}\text { V19. Favorable curriculum for the employment } \\
\text { market }\end{array}$ \\
\hline F04 & Teaching Quality & V23. Course demanding level \\
& & V25. Preparation for the employment market \\
& & V27. Quality academic services \\
& & V24. Sufficient practical activities \\
\hline F05 & Competence & V13. Correct information \\
& & V17. Qualified tutors \\
\hline F06 & Communication & V04. Coherent communication \\
& & V03. Effective advertisements \\
\hline F07 & Innovation and Longevity & V02. Innovative image \\
& & V07. Time of existence \\
\hline
\end{tabular}

Table 3 - Distribution of variables among the factors extracted

Source: Prepared by the author (2014)

We can observe that the most significant factor loadings exceed the value of 0.70 , which is a sign of having a well-defined structure in the extraction of factors, which as clarified by Costello and Osborne (2005), is the objective of every factor analysis. The final rotation, which met all the criteria, is shown in Table 4 below.

Table 4 - Factors Extracted for Cognitive Image

\begin{tabular}{|c|c|c|c|c|c|c|c|}
\hline \multirow[t]{2}{*}{ Variables } & \multicolumn{7}{|c|}{ Components } \\
\hline & F1 & F2 & F3 & F4 & F5 & F6 & F7 \\
\hline V02. Innovative image & 0.010 & 0.224 & 0.210 & 0.142 & -.001 & -.196 & 0.770 \\
\hline V03. Effective advertisements & -.040 & -.106 & 0.173 & 0.329 & 0.162 & 0.710 & 0.203 \\
\hline V04. Coherent communication & 0.090 & 0.216 & 0.141 & 0.094 & -.164 & 0.849 & -.068 \\
\hline V07. Time of existence & 0.154 & -.075 & 0.104 & 0.123 & 0.066 & 0.410 & 0.733 \\
\hline V09. Easy access to learning materials & 0.845 & 0.183 & 0.053 & 0.066 & 0.196 & 0.086 & -.100 \\
\hline V10. Ease of use of the platform & 0.862 & 0.060 & 0.128 & 0.085 & 0.187 & 0.026 & 0.168 \\
\hline V11. Quality of the platform & 0.655 & 0.130 & -.119 & 0.015 & 0.460 & 0.011 & 0.046 \\
\hline V12. Interface facilitator of EAD activities & 0.803 & 0.075 & 0.280 & 0.100 & -.084 & -.023 & 0.114 \\
\hline V13. Correct information & 0.246 & 0.144 & 0.328 & 0.125 & 0.735 & -.021 & 0.118 \\
\hline V14. Willingness to solve problems & 0.253 & 0.693 & 0.344 & 0.072 & 0.210 & -.051 & -.043 \\
\hline V15. Deadline for reply & -.066 & 0.773 & -.158 & 0.125 & 0.223 & 0.001 & 0.081 \\
\hline V16. Trained tutors & 0.119 & 0.696 & 0.180 & 0.073 & -.072 & -.023 & -.068 \\
\hline V17. Qualified tutors & 0.180 & 0.299 & 0.168 & 0.248 & 0.688 & -.053 & -.047 \\
\hline V18. Coherence of disciplines & 0.266 & -.041 & 0.675 & 0.022 & 0.195 & 0.195 & 0.445 \\
\hline $\begin{array}{l}\text { V19. Favorable curriculum for the employment } \\
\text { market }\end{array}$ & 0.250 & -.035 & 0.533 & 0.174 & 0.402 & 0.288 & 0.362 \\
\hline V21. Coherent evaluations & 0.002 & 0.201 & 0.779 & 0.245 & 0.093 & 0.128 & 0.117 \\
\hline V22. Evaluations compatible with the EAD & 0.141 & 0.187 & 0.796 & 0.187 & 0.125 & 0.078 & 0.038 \\
\hline V23. Course demanding level & 0.126 & 0.015 & -.045 & 0.822 & 0.139 & 0.179 & 0.123 \\
\hline V24. Sufficient practical activities & 0.166 & 0.379 & 0.346 & 0.596 & 0.010 & -.183 & 0.064 \\
\hline V25. Preparation for the employment market & -.065 & -.003 & 0.335 & 0.776 & 0.065 & 0.179 & 0.022 \\
\hline V27. Quality academic services & 0.230 & 0.296 & 0.206 & 0.594 & 0.214 & 0.205 & 0.168 \\
\hline V28. Quality administrative services & 0.102 & 0.609 & 0.074 & -.055 & 0.285 & 0.178 & 0.159 \\
\hline V30. Society recognition & 0.417 & 0.532 & 0.137 & 0.283 & -.183 & 0.236 & 0.186 \\
\hline
\end{tabular}

Source: Research data (2014)

The factors explain $72.458 \%$ of the total variance and were calculated based on the eigenvalue criterion, where we deleted the factors that presented eigenvalues lower than one. Hair Junior et al. (2005) adopted $60 \%$ as the minimum value, considered as satisfactory, to explain the total variance. 


\section{DISCUSSION AND ANALYSIS OF RESULTS}

Studies by Palacio, Meneses and Pérez (2002); Duarte, Alves and Raposo (2010); Maric, Pervlin and Ferjan (2010); Cervera et al. (2012) and Azoury, Daou and Khoury (2014) demonstrated that the image of higher education institutions is influenced by several variables. The scale used for this study met such observations, with seven factors in the factor analysis to measure the cognitive image being raised.

The results, based on Landry, Griffeth and Hartaman (2006) highlighting the difference in the way that the distance mode takes place and the need to establish what is most valuable for such students, indicated that, in addition to the Affective Image, the "Quality" and "Tutors and Staff" are the factors that are significantly associated with the Global Image of institutions. The following equation describes the significant relationship between the cognitive, affective and global images, with the tests applied at 95\% confidence, considering as significant associations with p-value lower than 0.05 (HAIR JUNIOR et al., 2005).

-Equation 1 - Association between Global Image (GI) and the factors "Teaching Quality" (TQ) and "Tutors and Staff” (TS):

$$
\mathrm{GI}=(-1.416 \mathrm{E}-16)+0.455 \text { "TQ" }+0.287 \text { "TS" }+\varepsilon
$$

-Equation 2 - Association between Affective Image (AI) and the factors "Virtual Environment" (VE) and “Teaching Quality" (TQ):

$$
\mathrm{AI}=(2.477 \mathrm{E}-16)+0.448 \text { "VE" }+0.237 \text { “TQ" }+\varepsilon
$$

- Equation 3 - Association between the Global Image (GI) and Affective Image (AI):

$$
\mathrm{GI}=(-1.061 \mathrm{E}-16)+0.456 \text { “AI” }+\varepsilon
$$

Regarding the influence of cognitive image on the global one, the factor "Teaching Quality" appeared as the most influential association. Palacio, Meneses and Pérez (2002) had already pointed out that the image perceived by the students determine their satisfaction with the institutions. Then, the result indicates that a reduction in the positive perception of the course demanding level, quality academic services, of sufficient practical activities and preparation for the employment market, all variables related to such factor, can reduce the Distance Learning students satisfaction, in relation to the course. Further on the "Teaching Quality" factor, considering that the educational project establishes practical classes (ANGULO MEZA et al. 2012) and that the institutions in the consortium are responsible for 
such projects (SOUZA NETO et al., 2010), as well as the academic activities of each course (HASAN; LAASER, 2010), managing its image is facilitated due to such control.

The association of the "Tutors and Staff" factor with the Global Image corroborates the studies by Comin, Oliveira and Possa (2013) and Garcia and Semensato (2015) who highlighted the link between students and the team of tutors. Thus, it is worth mentioning the importance of selecting a good mentoring team, considering not only qualification elements, but also aptitude, considering that being qualified exercise an activity does not necessarily mean that the individual has the ability to do so.

Moreover, since the tutors are not part of the teaching staff for the CEDERJ consortium institutions (HACKMAYER; BOHADANA, 2014), plus the fact that the assignment of administrative staff be of municipalities where the hub are (SOUZA NETO et al., 2010), with both not being directly linked to the organization structure, it can reduce the commitment towards the performance of activities, negatively influencing, in the perception of students in relation to interactions with such a component of the image. This can neutralize or destroy the positive perceptions of the institution if expectations are not met. Therefore, a perfect harmony is necessary between all organizational activities.

In turn, the equations also show that Affective Image is associated most strongly with the "Virtual Environment" factor (VE),

Por sua vez, as equações também revelam que a Imagem Afetiva está associada mais fortemente ao fator "Ambiente Virtual" (AV), also being impacted by the fator "Teaching Quality". The result highlights another factor that, according to the collected sample, relates to the image of the surveyed institutions and that is not under its control, as highlighted by Hasan and Laaser (2010).

Problems on the platform will reflect directly on the teaching-learning process, in the case of Distance Learning, which is possible to have negative effects on the students' experience and therefore, their perception in relation to the image of the institutions where they attend. Thus, whereas the students of distance education develop most of their activities in the virtual environment and use it to interact with educational institutions and other students, it is natural that this factor has been the one with the greatest connection with the affective image suggesting that it is important to establish and develop practical platform, with a nice interface and easy to use and allowing an effective interaction among its users and the institution. 
Balmer and Grayser (2006) declare that the corporate image is an answer to the question: "how is the company is being perceived now?". Thus, the image of the institutions may be compromised, even if the quality of education is ensured, if there is no effective management of the platform, avoiding problems in their access and use.

The equations also indicate that the most significant association with Global Image (GI) is exercised by the Affective Image (AI). The research corroborates Dowling (1986), who indicated the multidimensional nature of corporate image - and it is rare for only one factor to completely demonstrate the image of the institution - , and Azoury, Daou and Khoury (2014), also point out the affective aspect to be the greatest contribution to the perception of the global image.

Based on Nguyen and Leblanc (2001), Palacio, Meneses and Pérez (2002) and Kundi, Nawaz and Khan (2010), the results show that the institutions should seek to adjust aspects of their identity to the beliefs and values of their target audience to awake favorable feelings in various interactions with it, leading to a positive perception of the affective image, which will contribute indirectly to the perception of a favorable global image. Such fact may not be an easy task for public higher education institutions, since according to Slavov and Slavov (2010), distance learning favors the gathering of students of various backgrounds interacting in the virtual environment.

\section{CONCLUSION}

Public higher education institutions due to the generosity of its services, have a differential compared to Private Higher Education Institutions. Perhaps this is why there are very few studies aimed at analyzing how these institutions are seen by its faculty and the general public. Thus, the present study sought evidence of which factors impact the perception of the image of the Public Higher Education Institutions, from students' viewpoint of distance learning.

The study showed that the image is the translation of impressions generated in the individual's interaction with the various organizational components, based on cognitive and affective aspects, according to their way of observing the environment. Such impressions are associated with internal and external elements, both for individuals who observe, as for the organization that is being observed.

The research converges with other studies, indicating the multidimensional aspect of the image, it is made up of cognitive and affective aspects, which together are associated with the 
global image of the institutions. In the study, the "Teaching Quality" factor appeared as quite expressive, also influencing the affective image, giving evidence to public higher education institutions on the importance of planning actions to ensure positive experiences for students, through planning the education program, ensuring the offer of sufficient practical activities in congruence with market needs, maintaining the demanding level of the course and preparing students for the employment market, in addition to instructing the administrative body, training it to ensure the quality of service, and seeking to acquire and communicate the curriculum congruency with market needs.

The global image was also strongly associated with the affective image, signaling that in the collected sample, for distance learning students, the image of the Public Higher Education Institutions also relates to the with aspects that cannot be raised up directly by organizations. This result gives evidence that the institutions should adjust aspects of their identity to the beliefs and values of their target audience, arousing feelings favorable in its many interactions, to produce a positive emotional image, which may contribute indirectly to the perception of a favorable global image. In this sense, considering that distance education allows students from different regions to have access to services provided by such institutions, combining aspects of their identity to the beliefs and values of the target-audience of distance learning courses, appears to be a challenge that must be overcome.

Regarding "Tutors and Staff", a well-made selection of the mentoring team is suggested, based not only qualification on aspects, but also on the aptitude for the exercise of such activity, in addition to offering constant training to tutors in order to develop and improve their potentialities. On the other hand, affective image is affected most significantly by the "Virtual Environment" factor, suggesting that institutions must ensure that their management, maintenance and update will not hinder the teaching-learning process, avoiding problems in their access and use, creating a practical platform, with a pleasant and easy to use interface, allowing interaction between users and the institution, as problems on the platform negatively influence the students' experience and therefore, their perception regarding the institution's image which they attend to.

Given the survey results, we can observe that the research objective was achieved, contributing to the expansion of studies on image, in the marketing area, and for the understanding of dynamics in Distance Learning. The research also contributed to a better understanding of the factors that are associated with the image of higher education institutions, more specifically of public institutions, through the survey of elements that 
impact on the perception of the Distance Learning students, on the image of such institutions. Associating marketing to public institutions, the study showed how marketing can be used in favor of such institutions, with no contradiction in applying its concepts to the reality of nonprofit institutions.

One limitation of the study was applying the research to students belonging to a single teaching hub, and all institutions surveyed belong to the same consortium. Thus, we suggest conducting the research with students attending distance learning courses in other hubs and other public institutions. Another limitation is related to the sample size, whose particularity of the population covered, with a high rate of non-active students, meant we had a sample close to the limit established by other studies involving factorial analysis.

For future studies, we suggest investigating with the students, what changes could be made in the factors surveyed in the study in order to raise the perception of the image of the surveyed institutions. Another suggestion would be to identify how the "Teaching Quality", "Tutors and Staff" and "Virtual Environment" factors interfere with the perception of the image of educational institutions that adopt distance learning programs and why other factors were not considered important.

We also suggest, to conduct the study in private institutions that offer distance learning courses, and compare the results obtained between the research. Finally, given that the models indicate that the variables were responsible for explaining $66 \%$ of the total variance of the global image, other elements must be searched in the literature and by observing reality that may be associated with the perception of the image of students of Distance Learning and include them in the research tool.

\section{CONTRIBUTIONS BY THE AUTHORS}

Fábio Reis da Costa contributed to the conception and design of scientific work, formulating ideas, collecting data, analyzing data, preparing the scientific article.

Anderson Soncini Pelissari contributed with the analysis and adjustment of the design of scientific work, analysis and adjustment in the formulation of ideas, analysis and adjustment for data collection, adjustment and adequacy in data analysis, analysis, adjustment and adequacy of the scientific article. 


\section{REFERENCES}

ABBAD, G. S.; ZERBINI, T.; SOUZA, D. B. L. Panorama das pesquisas em educação a distância no Brasil. Estudos de Psicologia, v.15, n.3, p. 291-298, 2010.

ABRATT, R.; KLEYN, N. Corporate identity, corporate branding and corporate reputations: reconciliation and integration. European Journal of Marketing, v. 46, n. 7/8, p. 1048-1063, 2012.

ALVESSON, M. Organization: from substance to image? Organization Studies, v.11, n.3, p. 373-394, Jan. 1990.

ANGULO MEZA, L.; SOARES DE MELLO, J.C.C.B.; GOMES JÚNIOR, S.F.

Benchmarking distance learning centers with a multiobjective data envelopment analysis model. In: HOLTZMAN, Y. (Org.). Advanced topics in applied operations management. Croácia: InTech, 2012. p. 183-200.

ARANHA, F; ZAMBALDI, F. Análise fatorial em administração. São Paulo: Cengage Learning, 2008, 168 p.

AZOURY, N.; DAOU, L.; KHOURY, C.E. University image and its relationship to student satisfaction: case of the Middle Eastern private business schools. International Strategic Management Review, v.2, n.1, p. 1-8, 2014.

BALMER, J. M. T.; GRAYSER, S. A. Corporate marketing integrating corporate identity, corporate branding, corporate communications, corporate image and corporate reputation. European Journal of Marketing, v. 40, n. 7/8, p. 730-741, 2006.

BERENS, G.; VAN RIEL, C. B. M. Corporate associations in the academic literature: three main streams of thought in the reputation measurement literature. Corporate Reputation Review, v. 7, n.2, p. 161-178, 2004.

BIELSCHOWSKY, C. E. Educação superior a distância do consórcio CEDERJ - Centro de educação superior a distância do estado do Rio de Janeiro. In: OLIVEIRA, F. B. (Org).

Educação corporativa. São Paulo: Pearson - Prentice Hall, 2005.

BOAS, A. A. V. et al. Tutors and university teachers' perception about quality assurance in distance education: the case of the undergraduate management course in Minas Gerais Brazil. In: GLOBAL ENGINEERING EDUCATION CONFERENCE (EDUCON), 2011, Amman. Anais... Amman: IEEE, 2011.

CECIERJ. Fundação Centro de Ciências e Educação Superior a Distância do Estado do Rio de Janeiro. Regulamento dos cursos de graduação do consórcio CEDERJ. Disponível em: $<$ http://www.unirio.br/cead/editais/arquivos-noticias/regulamento-dos-cursos-de-graduacaodo-consorcio-cederj>. Acesso em: 18 dez. 2014.

CEDERJ. Centro de Educação Superior a Distância do Estado do Rio de Janeiro. Consórcio CEDERJ. Disponível em: 〈http://cederj.edu.br/cederj/sobre/>. Acesso em: 18 dez. 2014.

2015.

Polos. Disponível em: < http://cederj.edu.br/cederj/polos/>. Acesso em: 05 dez. 
CERVERA, A. et al. Medición de La imagen de La universidad y SUS efectos sobre la identificación y lealtad del egressado: uma aproximación desde el modelo de Beerli y Díaz (2003). Revista Española de Investigación em Marketing ESIC, v. 16, n.2, p. 7-29, 2012.

CHIN, W. W.; MARCOLIN, B. L.; NEWSTED, P. T. A partial least squares latent variable modeling approach for measuring interaction effects: results from a Monte Carlo simulation study and voice mail emotion / adoption study. Information systems research, v. 14, n.2, p. 189-217, 2003.

CLARO, T. A docência no consórcio CEDERJ: interatividade ou transmissão. In: ENCONTRO DE EDUCAÇÃO E TECNOLOGIAS DA INFORMAÇÃO E DA COMUNICAÇÃO. 5, 2007, Rio de Janeiro. Anais... Rio de Janeiro: E-TIC, 2007.

CLEMENTE, F. A. S.; JEUNON, E. E. A percepção dos jovens sobre a imagem organizacional da companhia Vale e o poder simbólico manifesto nos discursos. Teoria e Prática em Administração, v.2, n.1, p. 56-85, 2012.

COMIN, L.; OLIVEIRA, F. M. G.; POSSA, A. D. O tutor e os aspectos afetivos da aprendizagem em educação a distância. In: SEMINARIO DE EDUCAÇÃO A DISTÂNCIA IFSC. 1, 2013, Florianópolis. Anais... Florianópolis: I SEMINÁRIO EAD IFSC, 2013.

CORRAR, L. J.; PAULO, E.; DIAS FILHO, J. M. Análise multivariada para os cursos de administração, ciências contábeis e economia. São Paulo: Atlas, 2009. 541 p.

COSTELLO, A. B.; OSBORNE, J. W. Best practices in exploratory factor analysis: four recommendations for getting the most from your analysis. Practical Assessment, Research \& Evaluation, v.10, n.7, 2005.

DA COSTA VIEIRA, P. R.; COUTO, R. D. R. B. Escala para avaliação de imagem corporativa de universidade com capital aberto: um estudo com modelagem de equações estruturais. Revista de Administração IMED, v.5, n.1, p. 98-112, 2015.

DOWLING, G. R. Managing your corporate images. Industrial Marketing Management, v.15, n.2, p. 109-115, 1986.

DUARTE, P. O.; ALVES, H. B.; RAPOSO, M. B. Understanding university image: a structural equation model approach. International Review on Public and Nonprofit Marketing, n. 1, v.7, p. 21-36, 2010.

FIRMINO, D. L. F.; VIEIRA, J. J. Consórcio CEDERJ: uma análise crítica. In: SEMINÁRIO INTERNACIONAL INCLUSÃO EM EDUCAÇÃO: UNIVERSIDADE E PARTICIPAÇÃO. 3, 2013, Rio de Janeiro. Anais... Rio de Janeiro: UP-3, 2013.

GARCIA, A.; SEMENSATO, E. N. Tutoring in distance learning: new educational practice. In: CONGRESSO INTERNACIONAL ABED DE EDUCAÇÃO A DISTÂNCIA. 21, 2015, Maringá. Anais... Maringá: CIAED, 2015. Disponível em:

$<$ http://www.abed.org.br/congresso2015/anais/pdfingles/BD_120.I.pdf> Acesso em: 20 fev. 2016.

GARLAND, R. The mid-point on a rating scale: is it desirable? Marketing Bulletin, v.2, p. 66-70, 1991. 
GREENER, S. Business research methods. BookBoon, 2008, 110 p.

HAIR JUNIOR, J. F. et al. Multivariate data analysis. 6. ed. USA: Pearson, 2005.

HACKMAYER, M. B.; BOHADANA, E. Professor ou tutor: uma linha tênue na docência em EAD. Revista Iberoamericana de Educación a Distancia, v. 17, n.2, p. 223-240, 2014.

HASAN, A.; LAASER, W. Higher education distance learning in Portugal-State of the art and current policy issues. European Journal of Open, Distance and E-learning, v. 13, n.2. 2010 .

INEP. Instituto Nacional de Estudos e Pesquisas Educacionais Anísio Teixeira. Censo da educação superior 2013. Brasília, DF, 2014. Disponível em: <www.inep.gov.br >. Acesso em: 07 jan. 2014.

Censo da educação superior 2012. Brasília, DF, 2013. Disponível em: <www.inep.gov.br >. Acesso em: 12 dez. 2013.

KUNDI, G. M.; NAWAZ, A.; KHAN, S. The predictors of success for e-learning in higher education institutions (HEIs) in N-W. F. P, Pakistan. Journal of Information Systems and Tecnology Management, v.7, n.3, p.545-578, 2010.

LAKATOS, E. M; MARCONI, M. A. Fundamentos de metodologia científica. 7. ed. São Paulo: Atlas, 2010.

LANDRY, B. J. L.; GRIFFETH, R.; HARTMAN, S. Measuring student perceptions of blackboard using the technology acceptance model. Decision Sciences Journal of Innovative Education, v.4, n.1, p.87-99, 2006.

LEVINE, D. M. et al. Estatística: teorias e aplicações. 5. ed. Rio de Janeiro: LTC, 2008.

LIOU, J. J. H.; CHUANG, M. L. Evaluating corporate image and reputation using fuzzy MCDM approach in airline market. Quality \& Quantity, v.6, n.44, p. 1079-1091, 2010.

MARIC, M; PAVLIN, J; FERJAN, M. Educational institution's image: a case study. Journal of Management, Information Systems and Human Resources, v.43, n.2, p. 58-65, 2010.

MEC. Ministério da Educação e Cultura. CNE - Apresentação. Disponível em:

<http://portal.mec.gov.br/cne/arquivos/pdf/2001/pces966_01.pdf〉. Acesso em: 10 jan. 2014.

MONDINI, V. E. D. et al. Instituições de ensino superior a distância: análise dos motivos de escolha. Revista Meta: Avaliação, v. 6, n. 16, p. 71-84, 2014.

MORAN, J. M. Avaliação do ensino superior a distância no Brasil. 2010. Disponível em: <http://www2.eca.usp.br/moran/wp-content/uploads/2013/12/avaliacao.pdf> Acesso em: 17 jan. 2015.

NGUYEN, N.; LEBLANC, G. Corporate image and corporate reputation in customers' retention decisions in services. Journal of Retailing and Consumer Services, v.8, n.4, p. 227-236, 2001. 
PADEN, N.; STELL, R. Branding options for distance learning programs: managing the effect on university image. International Journal of Instructional Technology and Distance Learning, v.3, n.8, p. 45-54, 2006.

PALACIO, A. B.; MENESES, G.D.; PÉREZ, P. J. P. The configuration of the university image and its relationship with the satisfaction of students. Journal of Educational Administration, v.40, n.5, p. 486-505, 2002.

PITHON, A. J. C. et al. Evaluation of collaborative enterprises networks: case study of Brazilian virtual enterprises. In: BAS, Á. O.; FRANCO, R. D.; GASQUET, P. G. (Orgs.). Balanced automation systems for future manufacturing networks: $9^{\text {th }}$ IFIP WG 5.5 International Conference. Valencia: Springer Berlin, 2010. p. 19-27

POLAT, S. The relationship between university student's academic achievement and perceived organizational image. Educational Sciences: Theory \& Practice, v.1, n.11, p. 257-262, 2011.

REIO, T. G.; SHUCK, B. Exploratory factor analysis: implications for theory, research, and practice. Advances in Developing Human Resources, v.17, n.1, p. 12-25.

RICHARDSON, R. J. Pesquisa social: métodos e técnicas. 3. ed. São Paulo: Atlas, 1999. 336 p.

RINDFLEISCH, A. et al. Cross-sectional versus longitudinal survey research: concepts, findings and guidelines. Journal of Marketing Research, v. 45, n. 3, p. 261-279, 2008.

SCHULER, M. Management of the Organizational Image: A method for organizational image configuration. Corporate Reputation Review, v.7, n.1, p. 37-53, 2004.

SLAVOV, B.; SLAVOV, R. Educação a distância, uma nova modalidade de ensino e a legislação brasileira. Revista Sapere, v.2, n.1, 2010.

SOUZA NETO, S. P. et al. Fatores de qualidade: pontos positivos do emprego da tecnologia EAD no curso de administração do consórcio CEDERJ - UFRRJ. In: CONGRESSO INTERNACIONAL ABED DE EDUCAÇÃO A DISTÂNCIA, 16., 2010, Foz do Iguaçu. Anais... Foz do Iguaçu: CIAED, 2010.Disponível em: <http://www.abed.org.br/congresso2010/trabalhos2.asp>. Acesso em: 10 jan. 2014.

SPÍNDOLA, M; MOUSINHO, S. H. CEDERJ: um caminho na direção da educação inclusiva. Revista Científica em Educação a Distância, v.1, n.2, p. 36-46, 2012.

SUNG; M. YANG; S.U. Toward the model of university image: the influence of brand personality, external prestige, and reputation. Journal of Public Relations Research, v.20, n.4, p. 357-376, 2008.

TUBILLEJAS, B.; CUADRADO, M.; FRASQUET, M. A model of determinant attributes of corporate image in cultural services. Nonprofit and Voluntary Sector Quarterly, v.40, n.2, p. 356-376, 2011.

UNESCO. United Nations Educational, Scientific and Cultural Organization. Global education digest 2012: comparing education statistics across the world. 2012. 
VERGARA, S. C. Métodos de pesquisa em administração. 4. ed. São Paulo: Atlas, 2010. $277 \mathrm{p}$.

WILKINS, S. HUISMAN, J. Student evaluation of university image attractiveness and its impact on student attachment to international branch campuses. Journal of Studies in International Education, v. 17, n. 5, p. 607-623, 2013. 